\title{
Mapping Global Research on International Financial Reporting Standards: A Scientometric Review
}

\author{
Oleh Pasko $^{1}$, Mykola Hordiyenko ${ }^{1}$, Fuli Chen ${ }^{1,2}$, Yarmila Tkal ${ }^{1} \&$ Yulia Abraham ${ }^{1}$ \\ ${ }^{1}$ Faculty of Economics and Management, Accounting and Taxation Department, Sumy National Agrarian University, \\ Sumy, Ukraine \\ ${ }^{2}$ School of Economics and Management, Henan Institute of Science and Technology, Xinxiang, China \\ Correspondence: Oleh Pasko, Faculty of Economics and Management, Accounting and Taxation Department, Sumy \\ National Agrarian University, Gerasym Kondratyev Str., 160, Sumy, 40021, Ukraine. Tel: 38-542-701-042. E-mail: \\ oleh.pasko@snau.edu.ua
}

Received: October 12, 2020

Accepted: December 24, 2020

Online Published: January 20, 2021

doi:10.5430/ijfr.v12n3p116

URL: https://doi.org/10.5430/ijfr.v12n3p116

\begin{abstract}
For the purpose to provide scholars with a more quantifiable and visualized snapshot of the realm of IFRS research (lingua franca in global business today) we conducted a scientometric review of 973 articles related to the issue published during the period from 2009 to 2020 and indexed in the Web of Science Core Collection. The findings show that the number of related articles has been increasing year by year. The global research on IFRS has been produced chiefly in the USA, England, Australia, China and Germany which not only generated majority of the high-yielding research institutions as well as productive authors but also countries of origins most of the prolific journals. Among the innumerable subject matters debated in these selected papers key are earnings management, information disclosure quality, accounting standards, the impact of IFRS, value relevance, and IFRS adoption. Since 2009, IFRS research bursts can be divided into three stages: 1) the period from 2009 to 2011 - mainly focused on the discussion of the concepts of IAS and IFRS; 2) the period from 2012 to 2014 turned to the theoretical level, and 3) from 2016 to 2020 when the research focused on the practical level. This scientometric review would complement and enrich existing literature by incorporating a quantitative perspective into it.
\end{abstract}

Keyworlds: IFRS, literature review, scientometric review, visualization, Citespace

\section{Introduction}

The International financial reporting standards (IFRS) have morphed in the last decade into a lingua franca for business worldwide. The IFRS's issuer the International Accounting Standards Board (IASB) declare that 144 jurisdictions now require the use of IFRS Standards for all or most publicly listed companies, while another 12 jurisdictions permit its use (IFRS Foundation, 2019). If we apply broader scope like "permitted but not required for domestic public companies" then actually only a handful of jurisdictions, namely Guatemala, Japan, Madagascar, Nicaragua, Panama, Paraguay, Suriname, Switzerland, Timor-Leste are non-IFRS-friendly at the moment, while the staggering majority of countries across the globe are requiring or permitting the IFRS use (IFRS Foundation, 2019). Nevertheless, IFRS research is a vibrant direction developing in its own pace with many subtle branches and few hot areas prominent at the moment. All these sub-areas are constantly in a state of flux contending for attention of readers and selling itself for researchers seeking of fitting and appropriate research questions. To get grasp of peculiarities of certain field and to comprehensively assess it there are review articles (which could be either qualitative or quantitative) that present the state of affairs, research fronts and retrospective development of a particular area of research.

In the literature on IFRS, scholars have investigated various issues related to the topic, including IFRS Adoption (mandatory and voluntary) in jurisdictions and firms (Abad, Cutillas-Gomariz, Sánchez-Ballesta, \& Yagüe, 2018; Abdullah \& Tursoy, 2019; Ahmed, Neel, \& Wang, 2013; Barth \& Israeli, 2013; Li, 2010; Riahi \& Khoufi, 2019), the convergence of a various set of standards (Black, 2012; Cao \& Patel, 2019), disclosures quality (Ahmed et al., 2013; Barth, Landsman, \& Lang, 2008) financial statement comparability (Brochet, Jagolinzer, \& Riedl, 2013a; Hasan, Cheung, \& Taylor, 2020; Huang \& Yan, 2020), IFRS 'inadaptability' in given jurisdiction due to institutional differences and disparity in reporting incentives (new institutional accounting) (Burgstahler, Hail, \& Leuz, 2006; 
Daske, Hail, Leuz, \& Verdi, 2013; Hail, Leuz, \& Wysocki, 2010; Leuz, 2010; Leuz, Nanda, \& Wysocki, 2003; Leuz \& Wysocki, 2016; Nobes, 2006; Wysocki, 2011) to name only a few directions.

Despite this backdrop, though, so far there have been only a few qualitative literature review studies. We should mention in this respect the paper on compliance with IFRS mandatory disclosure requirements for the post-2005 period (Tsalavoutas, Tsoligkas, \& Evans, 2020), d'Arcy \& Tarca's paper reviewing 42 studies from 2008 to early 2017 about IFRS goodwill accounting choices for recognition, impairment, and disclosure of goodwill (d'Arcy \& Tarca, 2018) and Păşcan's article which studies the effect of the transition from the national accounting standards to IFRS on accounting quality in Europe, based on the research literature (Păşcan, 2015).

For the purpose to provide scholars with a more quantifiable and visualized snapshot of the realm we conducted a scientometric review of 973 articles related to the issue published during the period from 2009 to 2020 and indexed in the Web of Science Core Collection. We believe that this scientometric review would complement and enrich existing literature by incorporating a quantitative perspective into it.

Our overall research objective is to map global research on IFRS over the last decade. This overall research objective is obtained through the accomplishment of three smaller objectives. Firstly, our goal is to present an overview of the publications related to IFRS. Secondly, one of our objectives is to discern and identify the key contributors in the domain in terms of the leading countries, prominent institutions conducting research, cooperation network of IFRS research institutions, influential authors those article cited the most, hot articles (most downloaded) etc. Thirdly, we are going to pinpoint research hotspot, burst hot spot and trend analysis in the field over the last decade that would be of importance for researchers while choosing research question for their papers. We utilize scientometric analysis as it supposed to objectively visualize the research status quo at the date. Often, ideas for research turn up as a result of the comparison of various contexts and from the inquisitive attitude towards grasping how similar and dissimilar constructs work in diverse settings. We believe that studies we analyze are of great importance for rousing interest in researchers to explore the deeper role and various interdependencies of IFRS application in a different jurisdiction and spur them into action.

The remainder of the papers is organized as follows. The next section devoted to the literature review which makes a critical assessment of your literature to the date. In the third section, we introduce the methodology, including clarification of the notion of Scientometrics, the search strategy employed for data collection as well as a short introduction of methods. Section 3 presents the results obtained. Finally, we summarize, highlight and discuss the key findings of the paper, its limitations and propose avenues for future research in section 4 .

\section{Literature Review}

The literature on IFRS is becoming more extensive as, as we will see later in this paper, research on this issue is becoming more and more popular with each passing year. Moreover, as this field of research grows, different branches of research are formed naturally, which investigate various offspring's from IFRS.

Of course, IFRS reviews are not new, as there are reviews on IFRS adoption (De George et al., 2016; Khlif \& Achek, 2016), on single standards (Merz, 2017), IFRS adoption in the singled out region (Jang et al., 2016; Tawiah \& Boolaky, 2019) as well as the impact of IAS/IFRS on quality of financial reporting (Wadesango et al., 2016). Having said that however it should be noted that all these papers use a completely different methodology, which contrasted those papers and our study. These reviews are qualitative, our review is quantitative, previous studies have researched the literature that is known to its authors, we research all sources drawing on the help of databases. And the very emergence of database brought to life the methodology we use, namely - mapping knowledge domains.

The palpable need for data and information visualization lead in 2003, the US National Academy of Sciences to propose the concept of mapping knowledge domains that described as "a newly evolving interdisciplinary area of science aimed at the process of charting, mining, analyzing, sorting, navigating, and displaying knowledge (Shiffrin \& Borner, 2004, p. 5183). Later Chen drawing on this concept endeavour to develop CiteSpace, a software that allows a more sophisticated bibliometric analysis method to deal with a large number of publications (Chen, 2017). Since then CiteSpace becomes one of the most representative knowledge mapping tools (Wu et al., 2019). This field is "aimed at easing information access, making evident the structure of knowledge, and allowing seekers of knowledge to succeed in their endeavours" (Shiffrin \& Borner, 2004, p. 5183).

To the best of our knowledge (all our efforts to find at least one similar research failed) this paper is the first to apply this methodology to IFRS domain, thus shedding more light on the realm and complementing the qualitative studies on the issue. 


\section{Methodology}

\subsection{What Is Scientometrics?}

In order to set the expectation at the appropriate level, it is worth to point out that a scientometric review is. Scientometrics deals with "the quantitative aspects of the process of science as a communication system" (Mingers \& Leydesdorff, 2015, p. 1). Unlike the sociology of science and philosophy of science, "scientometrics focuses on texts (documents) as empirical units of analysis" (Leydesdorff \& Milojević, 2012, p. 4). The distinction of scientometrics from the sociology of science and philosophy of science presented in Figure 1.

\section{Content; Theories}

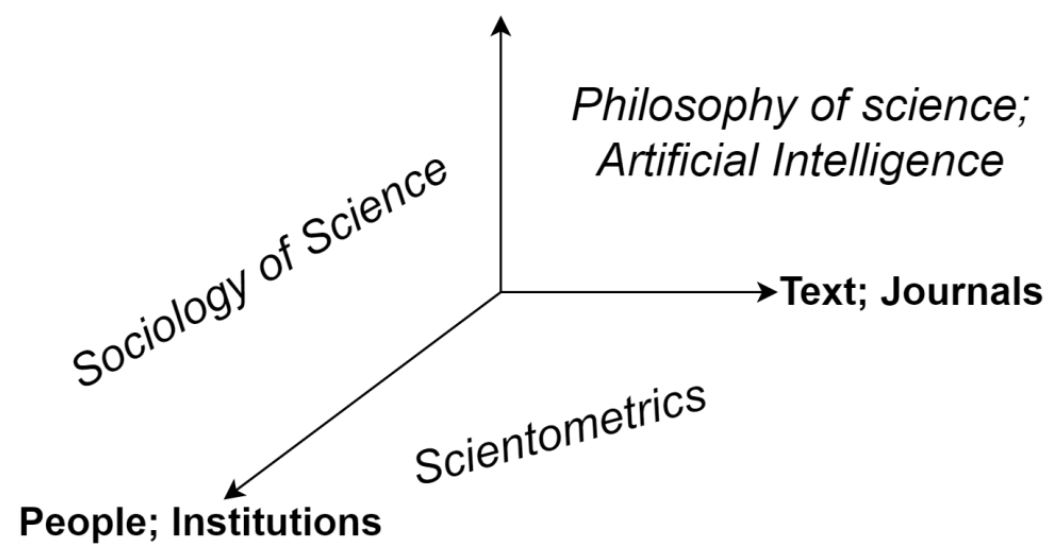

Figure 1. Three main dimensions in the dynamics of the sciences

(Leydesdorff \& Milojević, 2012, p. 4)

While scientometrics can study many other aspects of the dynamics of science, "in practice it has developed around one core notion - that of the citation" (Mingers \& Leydesdorff, 2015, p. 2). The citing provides the requisite linkages between people, ideas, journals and institutions "to constitute an empirical field or network that can be analysed quantitatively" (Mingers \& Leydesdorff, 2015, p. 2). Behind this, in turn, is Eugene Garfield who first discerned the significance of the citation and stood behind the creation of the Science Citation Index in the 1950s (now part of Clarivite Analytics's Web of Science) as a database for capturing citations (de Bellis, 2014; Garfield, 1955). Contrary to nowadays most pervasive use (research evaluation) its initial purpose was "rather help for researchers to search the literature more effectively - citations could work well as index or search terms, and also enabled unfamiliar authors to be discovered" (Mingers \& Leydesdorff, 2015, p. 2). That is what we are going to do - to discover for researchers unfamiliar authors (although known in the world) and open up new venues for their scholarly pursuit.

\subsection{Data Collection}

The data we obtained from The Web of Science Core Collection, an online scientific citation indexing service managed by Clarivate Analytics. We adduce following rationale which guided our choice. First of all, although it is not a single existing in the world nevertheless it is recognized as one of the world's leading databases (Rousseau, Egghe, \& Guns, 2018). Web-based Web of Science was first launched in 1997 (Liu, 2019; Rousseau et al., 2018) and then changed its name to the Web of Science Core Collection around 2014. Clarivate Analytics states that Web of Science Core Collection "includes over 21,000 peer-reviewed, high-quality scholarly journals published worldwide...; over 205,000 conference proceedings; and over 104,000 editorially selected books» and also "track ideas across disciplines and time from almost 1.7 billion cited references from over 155 million records"(Clarivate Analytics, n.d.). The second argument is that it enables scholars to extract directly the bibliographic information linked to the singled out records, thus being an ideal data source for carrying out a scientometric review. Thirdly, it allows researchers to fine-tune and tailor the results to further analysis like finding the most prolific authors and leading journals and it also creates citation reports for each of them. Therefore, to ensure the authority and pertinent academic level of the source data, and high level of filters available after the initial search the data studied in this article comes from the Web of Science Core collection database. 
In this study, we set to collect the largest amount available of pertinent papers related to IFRS research over the last decade (2009-2020) while the search confides to SCI-EXPANDED, SSCI, CPCI-S, CPCI-SSH, CCR-EXPANDED, IC indexes. Here, we must acknowledge that inevitably some pertinent papers, above all those was those published in languages other than English, had escaped our attention due to the fact that journals, where those articles was published, are not indexed in the abovementioned indexes.

IFRS is a multidisciplinary research topic involving accounting practice, economic theory, and business management. To focus on the scope of the analysis, we restrict the language to English, the document type to an article, and the subject headings to "IFRS" and "International Financial Reporting Standard" research documents. The initial search gave 1256 search results. Because the abbreviation of "IFRS" also stands for "intumescent flame retardants" and "individual funding request", we limited the subject categories to economics, management, business, public management, and international relations. Thus, our final search result was 973 articles.

The final search formula is: ((TS='IFRS' or TS='International Financial Reporting Standard') not (TS='poly' or TS='health') AND LANGUAGE: (English) AND DOCUMENT TYPES: (Article) Refined by: WEB OF SCIENCE CATEGORIES: (BUSINESS FINANCE OR ECONOMICS OR MANAGEMENT OR BUSINESS OR PUBLIC ADMINISTRATION OR INTERNATIONAL RELATIONS) Timespan: 1985-2020. Indexes: SCI-EXPANDED, SSCI, CPCI-S, CPCI-SSH, CCR-EXPANDED, IC.

\subsection{Research Methods}

Currently commonly used knowledge graph tools include CiteSpace, BibExcel, UciNet, VOSviewer, etc. This study utilizes the CiteSpace version of 5.7.R1 (64bit), which was invented by C.M. Chen at Drexel University in 2004 (C. Chen, 2004). CiteSpace today is widely used freely available Java application helping the researchers in an easy-to-grasp manner to visualize and analyse trends and patterns in the scientific literature (D. Chen, Liu, Luo, Webber, \& Chen, 2016). CiteSpace since its creation has accrued authority in the scholarly community due to its features such as analyzing and visualizing the knowledge maps of bibliographic records, especially those retrieved from the Web of Science (D. Chen et al., 2016; Kim \& Chen, 2015). It displays the complex relationships between knowledge units or knowledge groups by displaying the co-occurrence of research keywords, co-cited articles, and burst keywords.

Compared to other software CiteSpace excels in showing betweenness centrality to identify the pivotal points in the selected knowledge domain, on top of presenting the major contributors and their underlying relationships (Wu, Wang, Wang, Zhang, \& Meyer, 2019).

To conduct a scientometric review of global research in IFRS, we applied collaboration analysis and keyword co-occurrence analysis techniques in CiteSpace. Studies focuses are searched through the high-frequency keywords over the period of study, whereas the emerging trends are detected based on the high-frequency key- words that first appeared within the most recent decade. The analysis methods and presentation forms used are as follows:

Table 1. Analysis method employed in this paper and its output

\begin{tabular}{|c|c|c|c|}
\hline Content analysed & Analytical method & Presentation form & $\begin{array}{l}\text { Number of figure or } \\
\text { Table in this paper }\end{array}$ \\
\hline Time distribution & Quantity Statistics & Histogram & Figure 2 \\
\hline $\begin{array}{l}\text { Country (region) } \\
\text { distribution }\end{array}$ & $\begin{array}{l}\text { Knowledge graph, quantity } \\
\text { statistics }\end{array}$ & $\begin{array}{l}\text { Co-occurrence map, } \\
\text { statistical table }\end{array}$ & Figure 3 , Table 2 \\
\hline Research institute & $\begin{array}{l}\text { Knowledge graph, quantity } \\
\text { statistics }\end{array}$ & $\begin{array}{l}\text { Co-occurrence map, } \\
\text { statistical table }\end{array}$ & Figure 4, Table 3 \\
\hline $\begin{array}{c}\text { Author's citation } \\
\text { status }\end{array}$ & Quantity Statistics & Statistics table & Table 4 \\
\hline Hot Literature & $\begin{array}{l}\text { Knowledge graph, quantity } \\
\text { statistics }\end{array}$ & $\begin{array}{l}\text { Co-occurrence map, } \\
\text { statistical table }\end{array}$ & $\begin{array}{c}\text { Figure 5, Figure } 6 \text {, } \\
\text { Table 5, Table } 6\end{array}$ \\
\hline Hot keywords & $\begin{array}{c}\text { Keyword co-occurrence } \\
\text { analysis }\end{array}$ & $\begin{array}{l}\text { Co-occurrence map, } \\
\text { statistical table }\end{array}$ & Figure 7, Table 7 \\
\hline Hot topics & Keyword clustering map & Co-occurrence map & Figure 8 , Table 8 \\
\hline Research trends & Knowledge Graph & Burst hot spot analysis & Table 9 \\
\hline
\end{tabular}




\section{Results}

\subsection{Descriptive Analysis}

\subsubsection{Overview of Publication Development}

The number of papers published in a field each year can directly show the popularity and development trend of research topics. Using Web of Science's search results statistics, we drew a statistical chart of the number of annual publications.

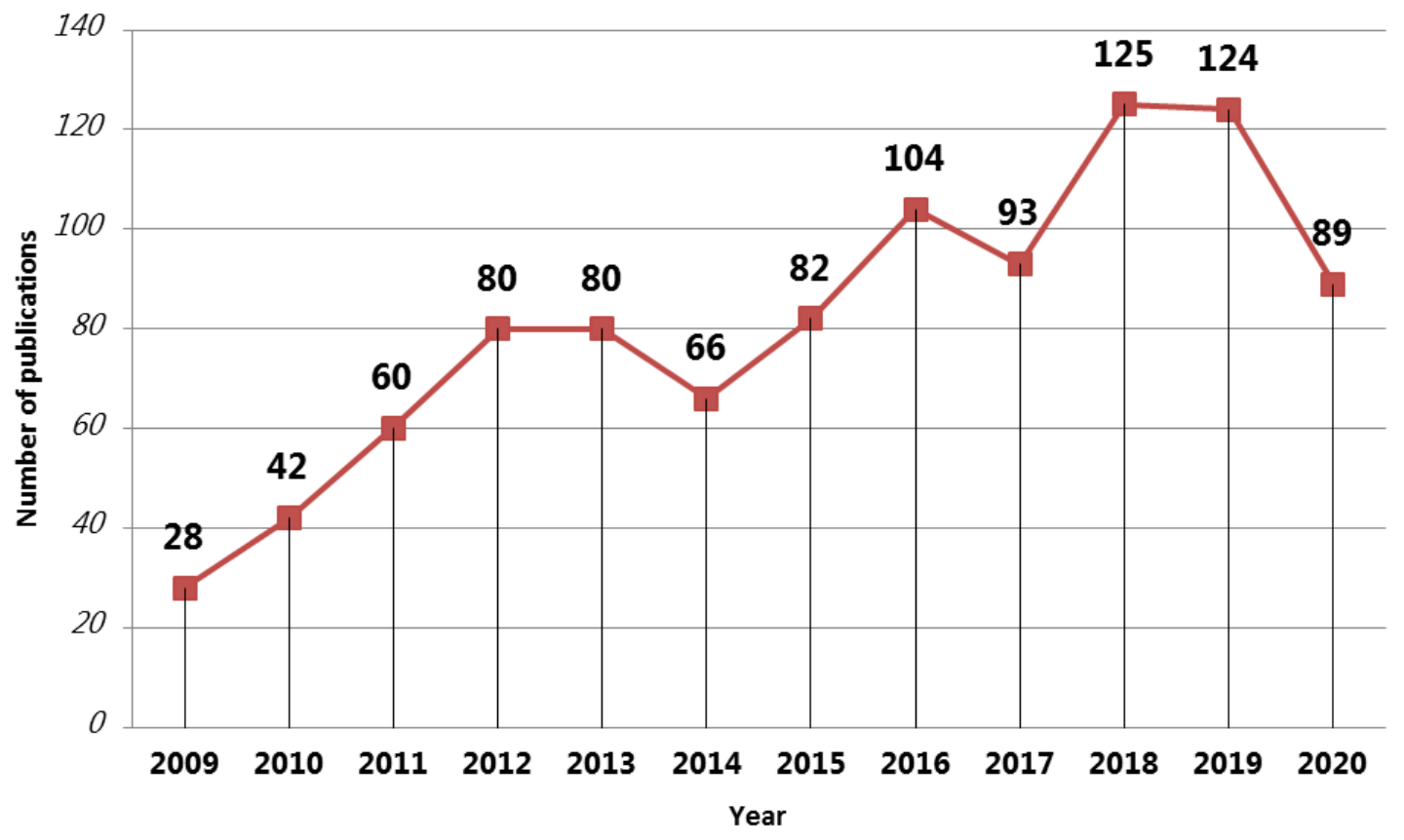

Figure 2. Number of articles published in IFRS related research over the years

Note: The data for 2020 is as of August 2020.

From the figure, we can see that since 2009, IFRS-related research began its upward trajectory. The number of related articles has been increasing year by year, with only a brief decrease in 2014 and 2017, but the overall we are witnessing an upward trend. Since the retrieval time is August 2020, the final data for 2020 will be higher than the data in the figure. It can be assumed that as more countries adopt IFRS or converge to IFRS, the number of articles on this topic will continue to increase.

\subsubsection{Geographical Distribution}

We first conduct a country-wise analysis to find out the impact of various jurisdictions on IFRS research at the geographical level. Through the statistics of the author's country (region), we can understand which countries (regions) researchers have made greater contributions to IFRS research. In CiteSpace, the time range is set to 2009-2020, and the slice length is 1 year. The source terms select "Title, Abstract, Author Keywords, Keywords Plus (ID)". Select "country" for the Node type. The selection criterion is "g-index=25". After running the analysis, we get 75 nodes, 229 connections, the connection density is 0.0825 (figure 3 ). 


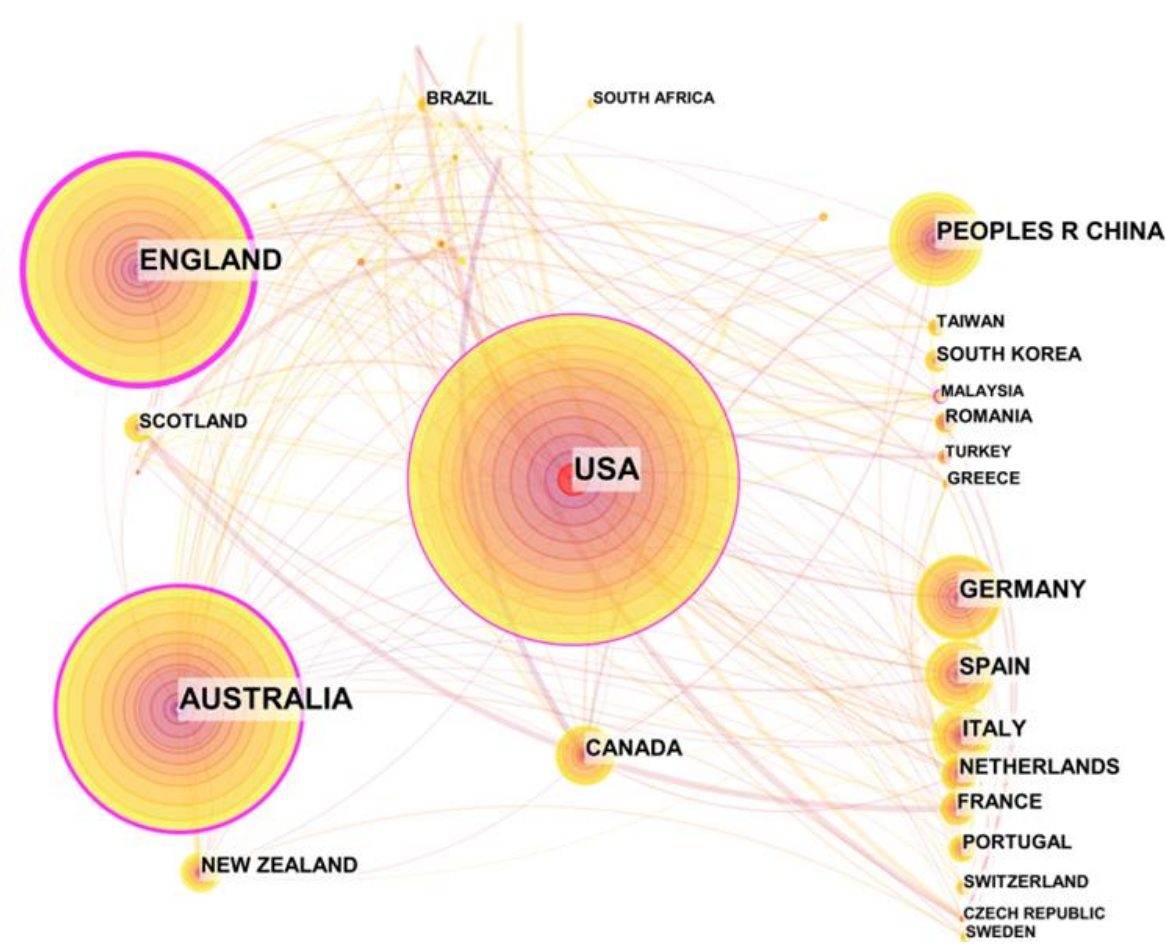

Figure 3. Country (region) distribution of IFRS research

Essentially, the prevalence of Anglo-Saxons countries is striking as contributions of the USA, England and Australia vastly outperform those of other developed countries. The results show that the top five highly ranked countries with publication counts are the USA, Australia, England, China and Germany, along with the betweenness centrality (BC) values of $0.16,0.35,0.55,0.03$ and 0.06 respectively.

Of particular interest is that the jurisdictions with high BC values, such as England (0.55), Australia (0.35) and USA (0.16), however, countries with high publication counts but low BC values like China (71), Germany (64), Spain (55) and Canada (49) may become crucial in the future. Exporting the network summary table, we get the country (region) distribution statistics of the IFRS study in Table 2.

Table 2. Country (region) distribution of IFRS research (Frequency>5)

\begin{tabular}{cccccccc}
\hline Freq & $\begin{array}{c}\text { Degree } \\
\text { Centralit } \\
\mathrm{y}\end{array}$ & $\begin{array}{c}\text { Betweennes } \\
\text { s Centrality }\end{array}$ & Country / Region & $\begin{array}{c}\text { Fre } \\
\mathrm{q}\end{array}$ & $\begin{array}{c}\text { Degree } \\
\text { Centralit } \\
\mathrm{y}\end{array}$ & $\begin{array}{c}\text { Betweennes } \\
\text { s Centrality }\end{array}$ & Country / Region \\
\hline 232 & 27 & 0.16 & USA & 19 & 5 & 0 & BRAZIL \\
\hline 173 & 33 & 0.35 & AUSTRALIA & 19 & 6 & 0.03 & ROMANIA \\
\hline 162 & 39 & 0.55 & ENGLAND & 18 & 7 & 0.02 & TAIWAN \\
\hline 71 & 14 & 0.03 & $\begin{array}{c}\text { PEOPLES R } \\
\text { CHINA }\end{array}$ & 17 & 7 & 0 & $\begin{array}{c}\text { SWITZERLAN } \\
\text { D }\end{array}$ \\
\hline 64 & 18 & 0.06 & GERMANY & 16 & 7 & 0 & GREECE \\
\hline 55 & 12 & 0.06 & SPAIN & 14 & 6 & 0.06 & $\begin{array}{c}\text { CZECH } \\
\text { REPUBLIC }\end{array}$ \\
\hline 49 & 15 & 0.06 & CANADA & 14 & 1 & 0 & $\begin{array}{c}\text { SOUTH } \\
\text { AFRICA }\end{array}$ \\
\hline
\end{tabular}




\begin{tabular}{cccccccc}
\hline 47 & 15 & 0.03 & ITALY & 14 & 8 & 0 & SWEDEN \\
\hline 34 & 14 & 0.09 & $\begin{array}{c}\text { NEW } \\
\text { ZEALAND }\end{array}$ & 13 & 6 & 0.02 & TURKEY \\
\hline 34 & 15 & 0.05 & $\begin{array}{c}\text { NETHERLAND } \\
\text { S }\end{array}$ & 13 & 12 & 0.12 & MALAYSIA \\
\hline 30 & 8 & 0.05 & FRANCE & 12 & 9 & 0 & BELGIUM \\
\hline 27 & 17 & 0.05 & SCOTLAND & 11 & 5 & 0.05 & JAPAN \\
\hline 24 & 7 & 0 & PORTUGAL & 11 & 8 & 0.02 & NORWAY \\
\hline 24 & 2 & 0 & SOUTH KOREA & & &
\end{tabular}

As can be seen from Table 2, there are 27 countries (regions) with more than 10 IFRS research articles. Betweenness Centrality represents the importance of this node and as can be seen in Table 2, the top 4 countries (regions) with the value of betweenness centrality are England, the United States, Australia, and New Zealand. The BC level of Germany, Spain, Canada, and the Czech Republic are all 0.06, but the Degree Centrality of Germany is higher. It can be considered that Germany is fourth more important countries in IFRS research after England, Australia and the USA. Surprisingly enough Malaysia with only 13 publications in our sample has emerged as a powerful contender with BC level of 0.12 and degree centrality of 12. Therefore, the USA, England, Australia, China, Germany and Malaysia are among the countries delivered the most significant impact on global IFRS research with both publication frequency and betweenness centrality taken into consideration.

\subsubsection{High-Yielding Institution Analysis}

Based on the statistics of research institutions, we can understand which institutions are conducting IFRS research and the number of articles produced by each institution. In CiteSpace, the time range is set to 2009-2020, and the slice length is 1 year. The source terms select "Title, Abstract, Author Keywords, Keywords Plus (ID)". Select "Institution" for the Node type. The selection criterion is "g-index=25". After running the analysis, we got 309 nodes, 216 connections, and the connection density is 0.0045 .

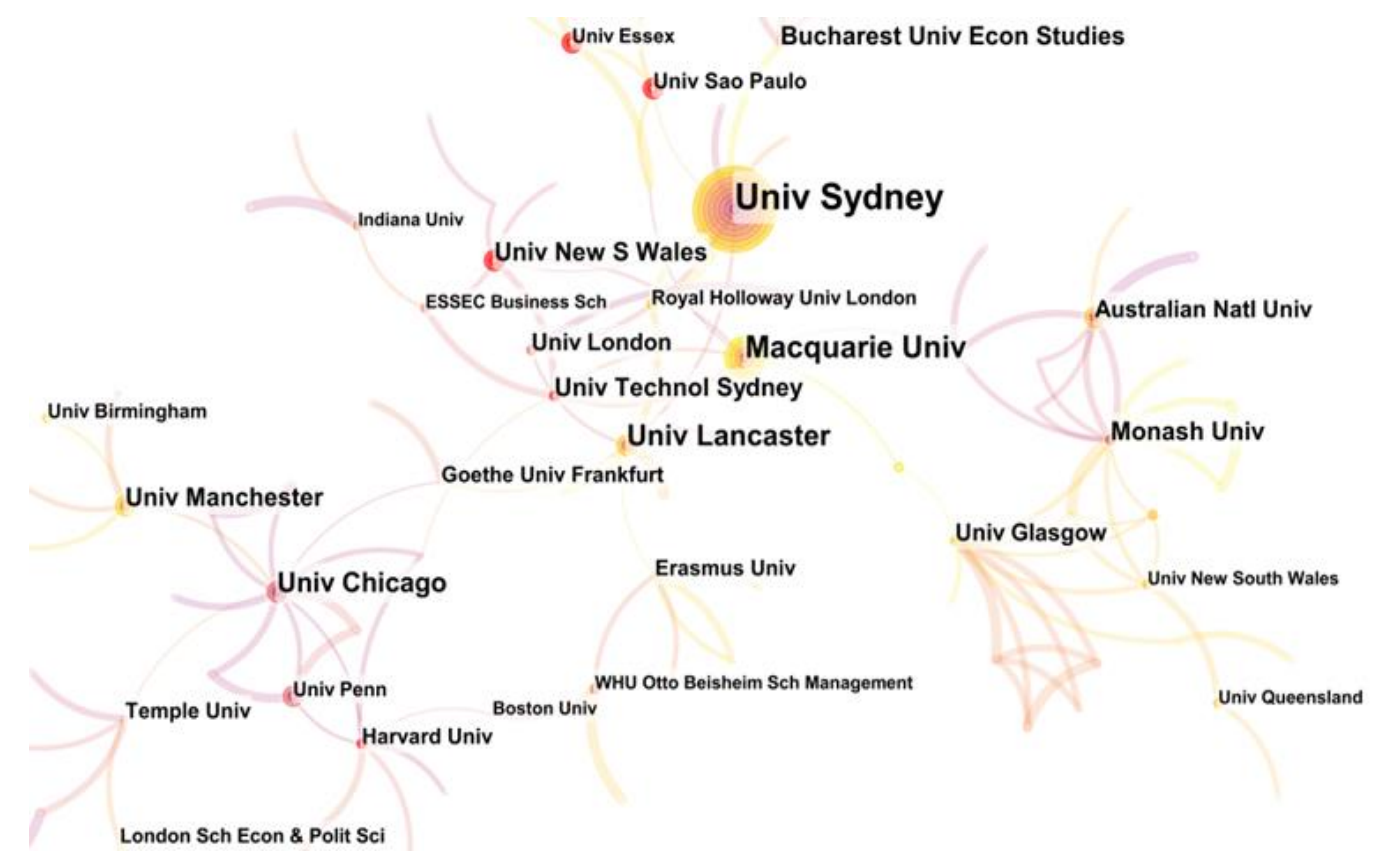

Figure 4. Co-occurrence map of cooperation network of IFRS research institutions 
Figure 4 shows that the main research institutions are universities. Although there is a cooperation between various research institutions, the cooperation network is relatively loose, and no high-intensity cooperation has been found.

Table 3. Statistics of research institutions (top10)

\begin{tabular}{lllll}
\hline № & Freq & Burst & Institution & Country \\
\hline 1 & 35 & & Univ Sydney & Australia \\
\hline 2 & 21 & & Macquarie Univ & Australia \\
\hline 3 & 17 & & Univ Lancaster & UK \\
\hline 4 & 14 & & Massey Univ & New Zealand \\
\hline 5 & 13 & 2.96 & Univ Chicago & USA \\
\hline 6 & 11 & 2.92 & Univ Technol Sydney & Australia \\
\hline 7 & 11 & 3.88 & Univ New S Wales & UK \\
\hline 8 & 10 & 2.77 & Monash Univ & Australia \\
\hline 9 & 10 & & Bucharest Univ Econ Studies & Romania \\
\hline 10 & 10 & & Univ Manchester & UK \\
\hline
\end{tabular}

The number of research published by various research institutions is very scattered. Among the 310 research institutions involved in this article, only 8 have published more than 5 articles, and the average number of articles published is 2.58. Among the top 10 research institutions for the number of published research papers, there are 4 universities in Australia, 3 universities in the UK, and 1 each in the United States, New Zealand and Romania. Among high-yielding institutions are the University of Sydney (35), Macquarie University (21), Lancaster University (17), Massey University of New Zealand (14) and The University of Chicago (13).

\subsection{Bibliometric Analysis}

\subsubsection{Productive Author Analysis}

Statistics on the citation of authors can show outstanding contributors to IFRS research. Table 4 lists the authors who have been cited more than 3 times. There are 26 people in total.

Table 4. Citation counts of the most productive authors

\begin{tabular}{llll}
\hline Freq & Author & Freq & Author \\
\hline 13 & Christopher Nobes & 4 & Martin Walker \\
\hline 9 & Christian Leuz & 4 & Yaowen Shan \\
\hline 8 & Sidney J Gray & 4 & Annita Florou \\
\hline 8 & Ann Tarca & 4 & Donna L Street \\
\hline 7 & Christian Stadler & 4 & Albert Tsang \\
\hline 5 & Begona Giner & 4 & Martin Glaum \\
\hline 5 & Edward J Riedl & 4 & Carolyn J Cordery \\
\hline 5 & Xi Li & 4 & Enrico Onali \\
\hline 5 & Luzi Hail & 4 & Chris Patel \\
\hline 5 & Edward Lee & 4 & Bill Huajian Yang \\
\hline 4 & Fawzi Laswad & 4 & Jayne M Godfrey \\
\hline 4 & Christopher W Nobes & 4 & Catalin Nicolae Albu \\
\hline 4 & Danqing Young & 4 & Ru Gao \\
\hline & & &
\end{tabular}


It can be seen from Table 4 that the author has been cited up to 13 times, and the top 5 most cited authors are Christopher Nobes, Christian Leuz, Sidney J Gray, Ann Tarca, Christian Stadler.

\subsubsection{Hot Articles}

By counting the number of times the article has been used, it can reflect the research hotspots in this field. The bibliographic information of Web of Science provides two fields U1 and U2 to reflect the number of times the article has been downloaded and saved as a bibliography. U1 represents the number of uses in the past 180 days, and U2 represents the number of uses since February 1, 2013. Through the analysis of the two fields U1 and U2, the research hotspots within six months and since 2013 can be filtered out.

In CiteSpace, the time range is set to 2009-2020, and the slice length is 1 year. The source terms select "Title, Abstract, Author Keywords, Keywords Plus (ID)". Select "Reference" for the Node type. The selection criterion is "Usage 180", top 120 items. We run the analysis and get 1067 nodes, 3071 connections, the connection density is 0.0054. In the control panel, set the Node Labels option, Threshold is set to 30, and the documents with more than 30 citations are displayed. The map parameters settings of "Usage 2013" is the same as this.

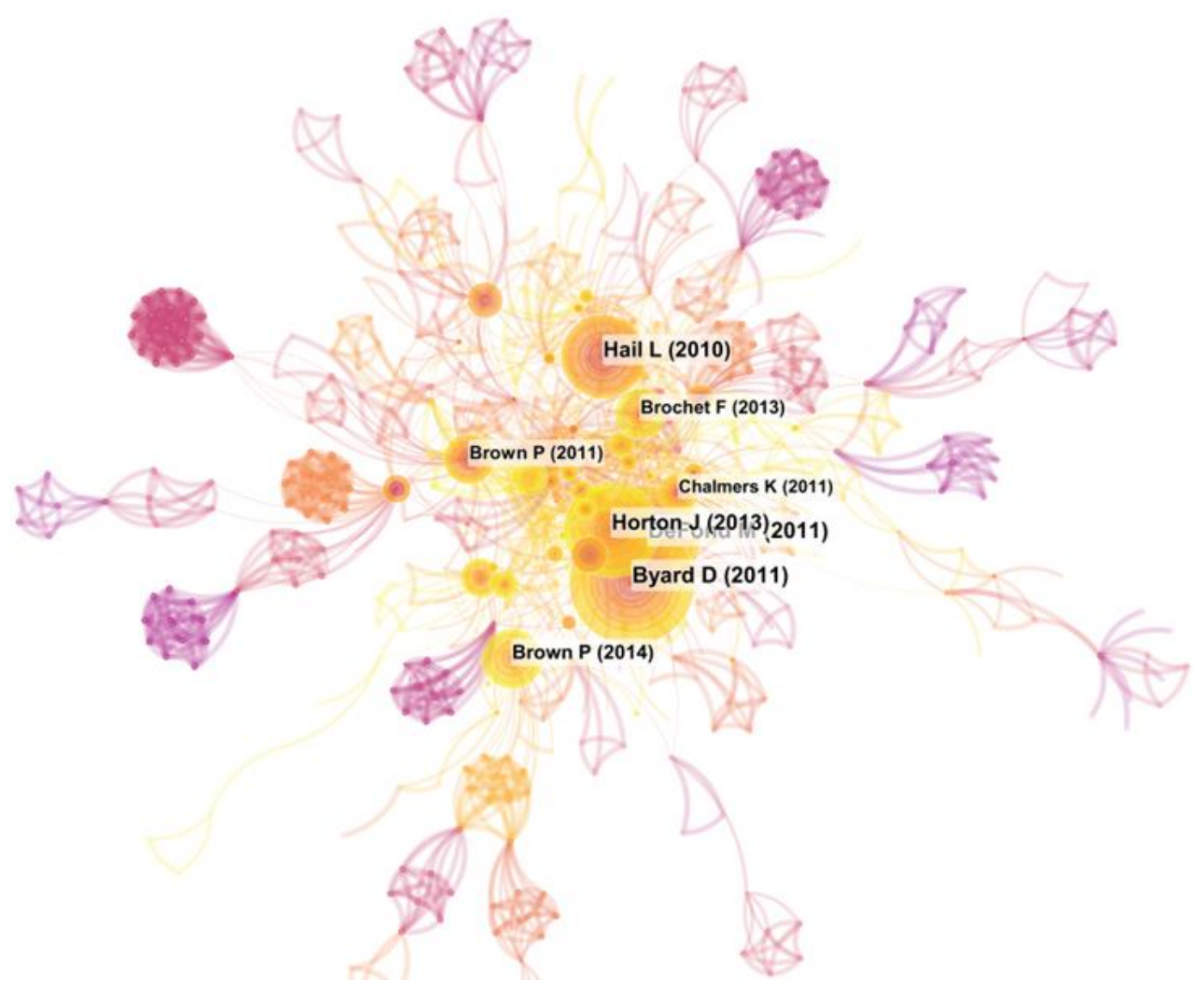

Figure 5. Document usage in 180 days 


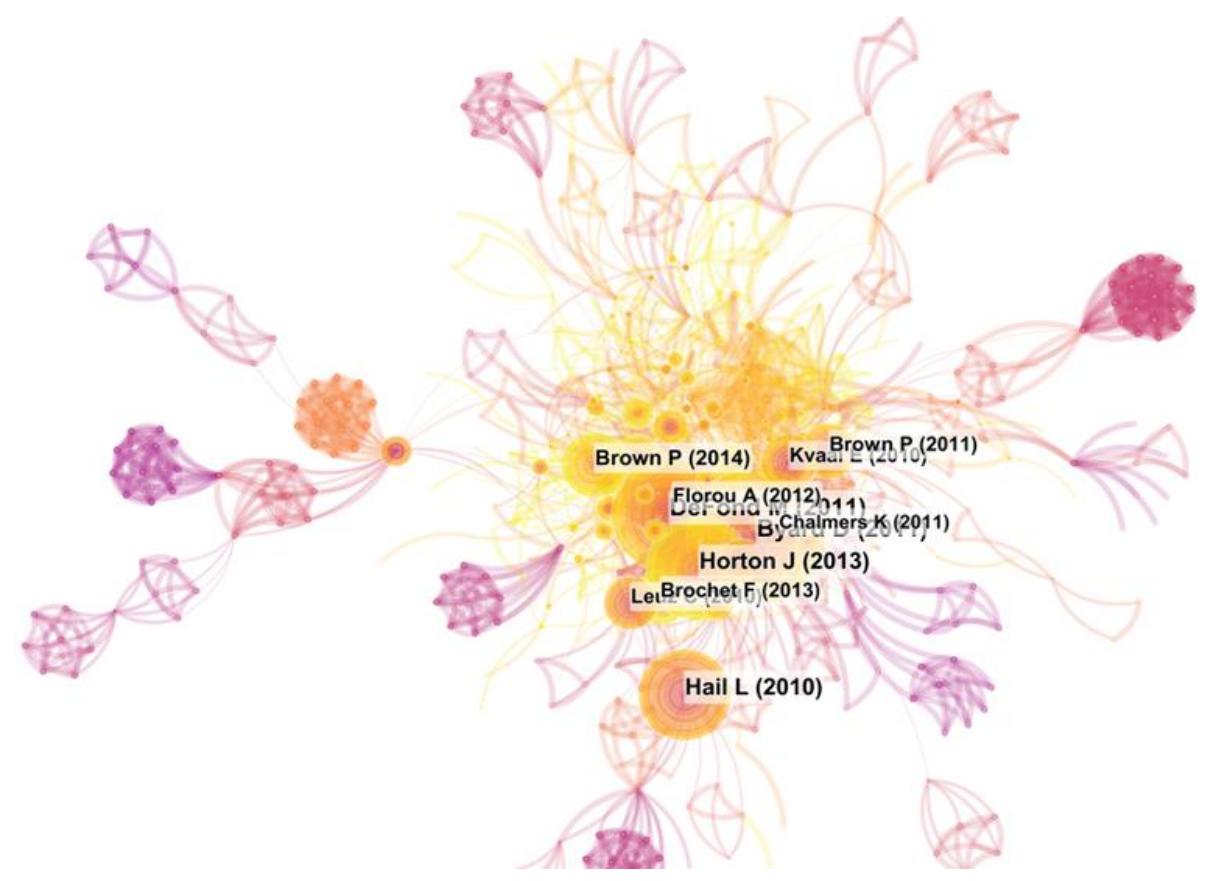

Figure 6. Literature usage since 2013

As can be seen from Figures 5 and 6, the documents used in IFRS research are basically the same within the last six months (the point of departure is August 2020) and since 2013. It is Byard, Li, \& Yu's article on the impact of mandatory adoption of IFRS on the information environment of financial analysts (2011), DeFond, Hu, Hung, \& Li's study on the impact of mandatory adoption of IFRS on foreign mutual fund ownership from the perspective of comparability (2011) and Horton, Serafeim, \& Serafeim's paper studying whether the mandatory adoption of IFRS can improve the information environment (Horton, Serafeim, \& Serafeim, 2013).

Table 5. Hot references in IFRS research

\begin{tabular}{|c|c|c|c|c|c|c|c|}
\hline NO. & Freq & Burst & Degree & Authors & Year & Source & DOI \\
\hline 1 & 87 & & 11 & Byard D & 2011 & J ACCOUNT RES & 10.1111/j.1475-679X.2010.00390.x \\
\hline 2 & 74 & 3.94 & 14 & $\begin{array}{l}\text { DeFond } \\
\mathrm{M}\end{array}$ & 2011 & $\begin{array}{l}\text { J ACCOUNT } \\
\text { ECON }\end{array}$ & 10.1016/j.jacceco.2011.02.001 \\
\hline 3 & 66 & 4.53 & 9 & Horton $\mathrm{J}$ & 2013 & $\begin{array}{l}\text { CONTEMP } \\
\text { ACCOUNT RES }\end{array}$ & 10.1111/j.1911-3846.2012.01159.x \\
\hline 4 & 61 & 7.65 & 12 & Hail L & 2010 & $\begin{array}{l}\text { ACCOUNT } \\
\text { HORIZ }\end{array}$ & 10.2308/acch.2010.24.3.355 \\
\hline 5 & 44 & 6.05 & 15 & Brown $\mathrm{P}$ & 2014 & $\begin{array}{l}\text { J BUS FINAN } \\
\text { ACCOUNT }\end{array}$ & 10.1111/jbfa.12066 \\
\hline 6 & 39 & 2.89 & 15 & Kvaal E & 2010 & $\begin{array}{ll}\text { ACCOUNT } & \text { BUS } \\
\text { RES } & \\
\end{array}$ & $10.1080 / 00014788.2010 .9663390$ \\
\hline 7 & 38 & & 19 & $\begin{array}{l}\text { Brochet } \\
\mathrm{F}\end{array}$ & 2013 & $\begin{array}{l}\text { CONTEMP } \\
\text { ACCOUNT RES }\end{array}$ & 10.1111/1911-3846.12002 \\
\hline 8 & 38 & & 23 & Florou A & 2012 & ACCOUNT REV & 10.2308/accr-50225 \\
\hline 9 & 38 & 4.59 & 24 & Leuz C & 2010 & $\begin{array}{ll}\text { ACCOUNT } & \text { BUS } \\
\text { RES } & \\
\end{array}$ & $10.1080 / 00014788.2010 .9663398$ \\
\hline 10 & 36 & & 36 & Brown $\mathrm{P}$ & 2011 & $\begin{array}{l}\text { ACCOUNT BUS } \\
\text { RES }\end{array}$ & $10.1080 / 00014788.2011 .569054$ \\
\hline
\end{tabular}


What articles about and its main findings in authors own words presented in Table 6.

Table 6. Highly cited papers findings in authors own words

\begin{tabular}{lll}
\hline \multicolumn{1}{c}{ Authors } & Title \\
\hline 1 (Byard et al., & $\begin{array}{l}\text { The Effect of Mandatory } \\
\text { IFRS Adoption on } \\
\text { Financial Analysts' } \\
\text { Information Environment }\end{array}$ \\
& \\
& \\
& \\
(DeFond et al., & $\begin{array}{l}\text { The impact of mandatory } \\
\text { IFRS adoption on foreign } \\
\text { mutual fund ownership: } \\
\text { The role of comparability }\end{array}$
\end{tabular}
Main findings in authors own words The study "highlights the important roles of enforcement regimes and firm-level reporting incentives in determining the impact of mandatory IFRS adoption" (2011, p. 70)

"This study examines the effect of adopting a uniform set of accounting standards (i.e., mandatory IFRS adoption) on comparability and cross-border investment...

Overall, our findings suggest that the effects of improved comparability associated with mandatory IFRS adoption on cross-border investment depend both on the institutional environment that shapes firms' reporting incentives and on the extent of increased number of industry peers using the same accounting standards" (2011, p. 256)

"We investigate whether mandatory IFRS adoption improves firms' information environment. We find that after the mandatory transition to IFRS, forecast accuracy and other measures of the quality of the information

(Horton et al., $\begin{aligned} & \text { Does Mandatory IFRS } \\ & \text { Adoption Improve the } \\ & \text { Information Environment? }\end{aligned}$
environment improve significantly more for mandatory adopters. Moreover, we find that the larger the difference between IFRS earnings and local GAAP earnings the larger is the improvement in forecast accuracy. This result increases our confidence that IFRS adoption causes the improvement in the information environment" (2013, p. 32)

\begin{tabular}{|c|c|c|c|}
\hline 4 & $\begin{array}{l}\text { (Hail et al., } \\
2010)\end{array}$ & $\begin{array}{l}\text { Global Accounting } \\
\text { Convergence and the } \\
\text { Potential Adoption of IFRS } \\
\text { by the U.S. (Part I): } \\
\text { Conceptual Underpinnings } \\
\text { and Economic Analysis }\end{array}$ & $\begin{array}{l}\text { Our analysis shows that the decision to adopt IFRS } \\
\text { mainly involves a cost-benefit trade-off between 1) } \\
\text { recurring, albeit modest, comparability benefits for } \\
\text { investors; 2) recurring future cost savings that will } \\
\text { largely accrue to multinational companies; and 3) } \\
\text { one-time transition costs borne by all firms and the U.S. } \\
\text { economy as a whole, including those from adjustments } \\
\text { to U.S. institutions. ( } 2010, \text { p. } 355 \text { ) }\end{array}$ \\
\hline 5 & $\begin{array}{l}\text { (Brown, } \\
\text { Preiato, \& } \\
\text { Tarca, 2014) }\end{array}$ & $\begin{array}{l}\text { Measuring Country } \\
\text { Differences in Enforcement } \\
\text { of Accounting Standards: } \\
\text { An Audit and Enforcement } \\
\text { Proxy }\end{array}$ & $\begin{array}{l}\text { "In this paper, we present an index designed to capture } \\
\text { differences between countries in relation to the } \\
\text { institutional setting for financial reporting, specifically } \\
\text { the auditing of financial statements and the enforcement } \\
\text { of compliance with each country's accounting } \\
\text { standards... We do this for } 51 \text { countries for each of the } \\
\text { years } 2002,2005 \text { and } 2008 \ldots \text { Preliminary tests suggest } \\
\text { our indices have additional explanatory power (over } \\
\text { more general legal proxies) for country-level measures } \\
\text { of economic and market activity, financial transparency } \\
\text { and earnings management" (2011, p. } 1)\end{array}$ \\
\hline 6 & $\begin{array}{l}\text { (Kvaal \& } \\
\text { Nobes, 2010) }\end{array}$ & $\begin{array}{l}\text { International differences in } \\
\text { IFRS policy choice: A } \\
\text { research note }\end{array}$ & $\begin{array}{l}\text { "we examine whether there are systematic differences in } \\
\text { IFRS accounting policies between countries. Using } \\
\text { information from the annual reports of companies in the }\end{array}$ \\
\hline
\end{tabular}


blue-chip indices of the largest five stock markets that use IFRS, we reject a null hypothesis that IFRS practice is the same across countries. For 16 accounting policy issues, we find instead significant evidence that preIFRS national practice continues where this is allowed within IFRS" (2010, p. 173).

"This paper investigates whether mandatory IFRS adoption leads to capital market benefits through enhanced financial statement comparability... Empirical results are consistent with these expectations, (Brochet, Mandatory IFRS Adoption with abnormal returns to insider purchases decreasing 7 Jagolinzer, \& and Financial Statement Riedl, 2013) Comparability following IFRS adoption across short (five-day) and long (one-, three-, and six-month) window return settings... We infer that these results are consistent with mandatory IFRS adoption reflecting capital market benefits attributable to improved comparability" (2013, p. 25)

"We examine whether the mandatory introduction of International Financial Reporting Standards leads to an increase in institutional investor demand for equities... Changes in holdings are concentrated around first-time annual reporting events. Second, we document that the positive IFRS effects on institutional holdings are concentrated among investors whose orientation and styles suggest they are most likely to benefit from higher quality financial statements, including active, value, and growth investors. These results are consistent with holdings changes being associated with the financial reporting regime change" (2012, p. 1993)

"This paper discusses differences in countries' approaches to reporting regulation and explores reasons why they exist in the first place and why they are likely Different approaches to to persist... It highlights that there are robust corporate reporting institutional clusters around the world. A key message of regulation: How jurisdictions differ and why this paper is that these clusters

are likely to persist in the foreseeable future given the complementarities among countries' institutions" (2010, p. 252)

"When countries have announced plans to adopt IFRS in lieu of the standards that had applied previously, they have referred to a number of benefits, mostly to do with equity markets. So it is not surprising that academics International Financial 10 (Brown, 2011) Reporting Standards: what are the benefits? have looked to equity markets to assess the extent to which benefits may have materialised. The evidence they have gathered can fairly be characterised as mixed, partly because of differences in samples and the use of a wide range of proxies for the same underlying but unobservable idea" (2011, p. 269)

Thus, the most cited articles address two main issues: the quality of information after the adoption of IFRS (Brochet et al., 2013; Brown, 2011; Florou \& Pope, 2012; Horton et al., 2013; Kvaal \& Nobes, 2010) and the problem of adaptation of IFRS in different institutional settings (Brown et al., 2014; Byard et al., 2011; DeFond et al., 2011; Hail et al., 2010; Leuz, 2010). 


\subsubsection{Research Hotspot}

The co-occurrence analysis of keywords in the research field can show the research hotspots in this field. In CiteSpace, the time range is set to 2009-2020, and the slice length is 1 year. Select "Term" and "Keyword" for the Node type. The selection standard is set to g-index $=35$, the pruning method is Pathfinder, and "Pruning sliced networks" and "Pruning the merged network" are selected. After running the analysis we got a total of 553 nodes and 1023 connections. The keyword co-occurrence map is shown in Figure 7.

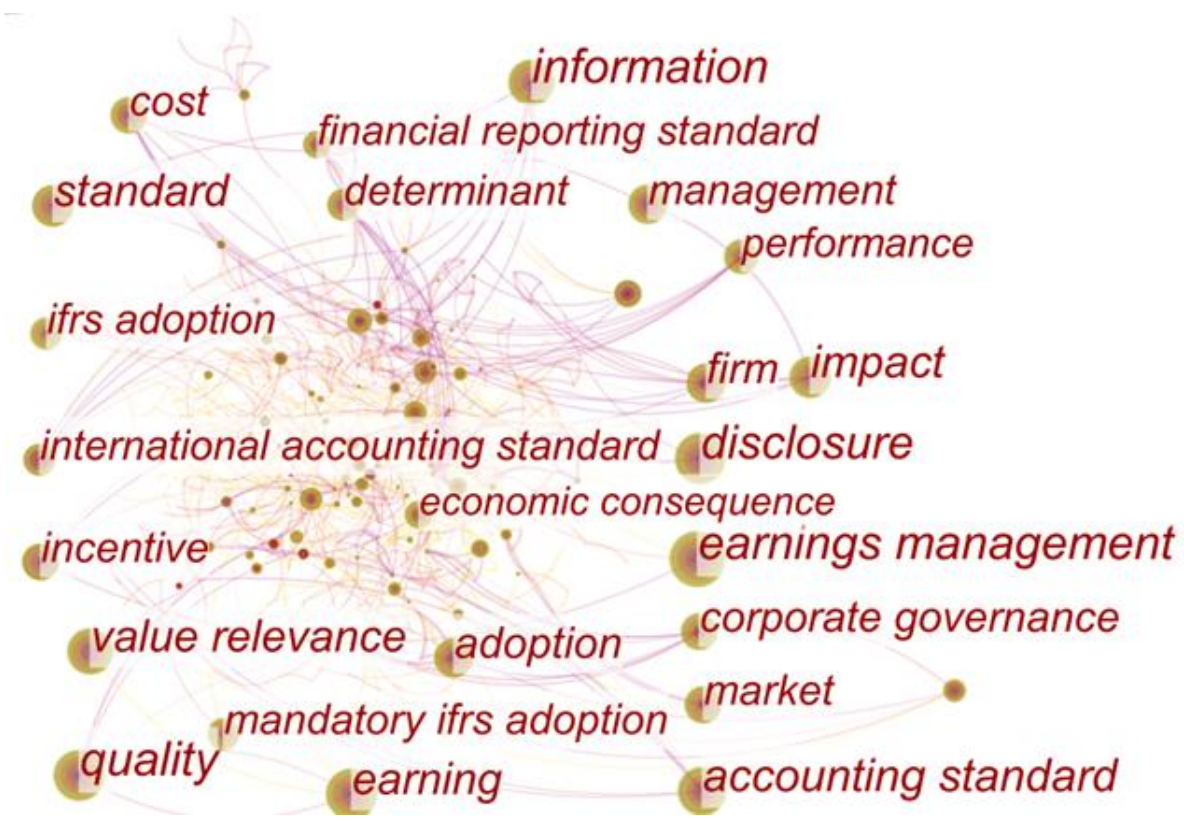

Figure 7. Co-occurrence map of hot keywords

Table 7 counts the hot keywords that appear more than 30 times.

Table 7. Frequency of occurrence of hot keywords ( $>30$ times)

\begin{tabular}{llll}
\hline Freq & Keyword & Freq & Keyword \\
\hline 153 & earnings management & 78 & IFRS adoption \\
\hline 147 & information & 75 & international accounting standard \\
\hline 146 & quality & 73 & performance \\
\hline 141 & disclosure & 70 & financial reporting standard \\
\hline 121 & accounting standard & 60 & economic consequence \\
\hline 112 & impact & 57 & fair value \\
\hline 107 & standard & 52 & investor protection \\
\hline 103 & value relevance & 48 & valuation \\
\hline 103 & earning & 44 & governance \\
\hline 95 & adoption & 44 & accrual \\
\hline 90 & corporate governance & 43 & risk \\
\hline 88 & firm & 43 & consequence \\
\hline 84 & market & 36 & ownership \\
\hline 83 & management & 34 & income \\
\hline 83 & determinant & 32 & conservatism \\
\hline
\end{tabular}




\begin{tabular}{llll}
\hline 81 & incentive & 31 & equity \\
\hline 81 & cost & 31 & accounting quality \\
\hline 80 & mandatory IFRS adoption & & \\
\hline
\end{tabular}

Figure 7 shows keywords with more than 60 occurrences except for the search keywords "IFRS" and "International Financial Report Standards". Table 7 shows keywords with more than 30 occurrences. Combining Figure 7 and Table 7, we can see that the top 10 keywords related to IFRS topics are: earnings management, information, quality, disclosure, accounting standard, impact, standard, value relevance, earnings, and adoption. These core keywords correspond to hot research topics in the corresponding fields, including earnings management, information disclosure quality, accounting standards, the impact of IFRS, value relevance, and IFRS adoption.

\subsubsection{Hot Research Topics}

Based on Figure 7, keyword clustering is performed. The Modularity Q value (Q value) is 0.7369 , and the Mean Sihouette value ( $\mathrm{S}$ value) is 0.7015 . It is generally believed that a $\mathrm{Q}$ value greater than 0.3 indicates a significant cluster structure, $\mathrm{S}$ value greater than 0.5 indicates a reasonable cluster structure, and $\mathrm{S}$ value greater than 0.7 indicates that the clustering is convincing. We get the keyword clustering map shown in Figure 8.

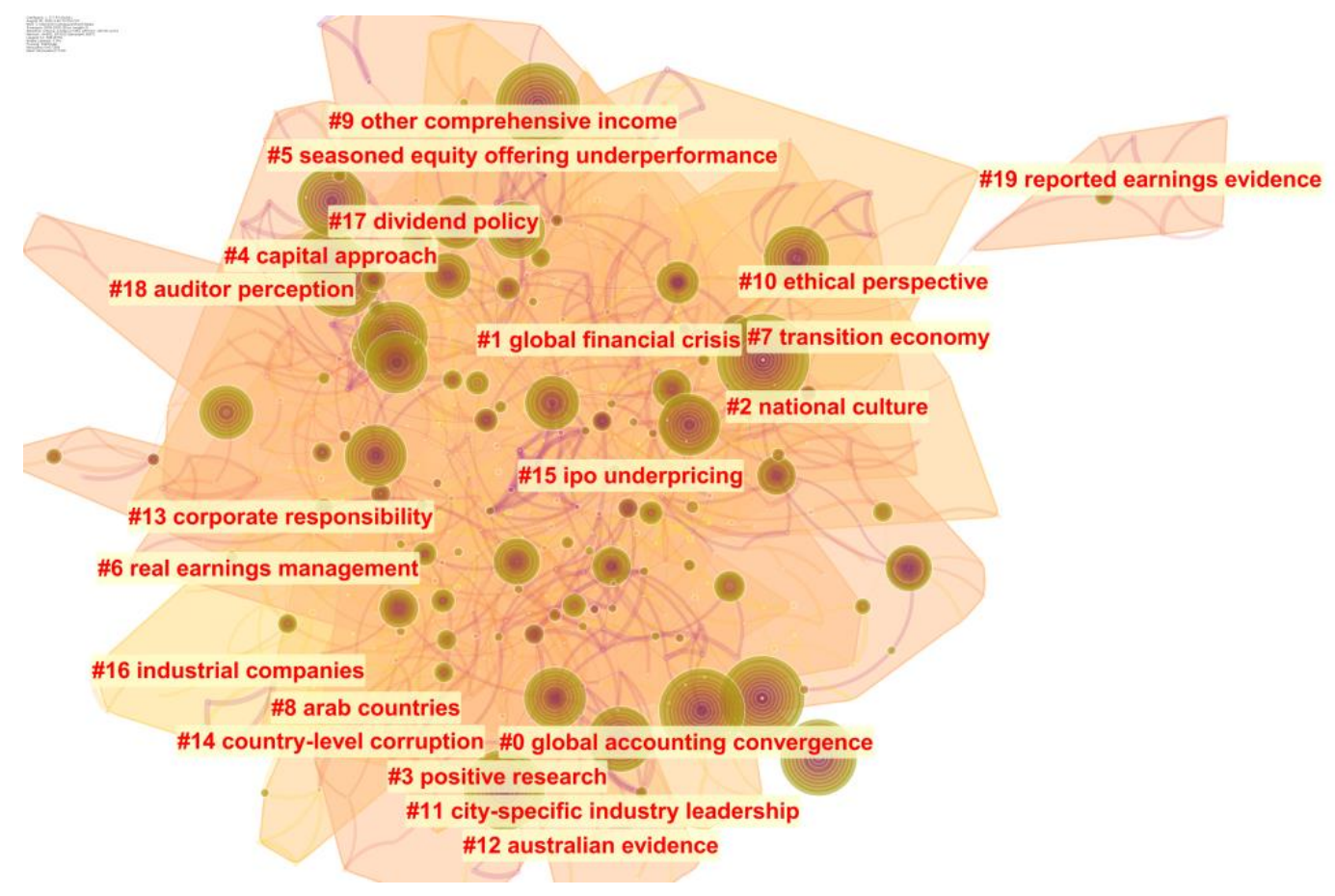

Figure 8. Hot keyword clustering

From the clustering results in Figure 8, it can be concluded that there are a total of 20 clustering keywords in the IFRS research field. Among them, the $\mathrm{S}$ values of the first 8 clusters are all greater than 0.7 (this means that the clustering is convincing). Table 8 shows the keywords of these clusters.

Table 8. Top 8 cluster keywords

\begin{tabular}{llll}
\hline ClusterID & Size & Silhouette & Cluster Label \\
\hline 0 & 46 & 0.862 & global accounting convergence \\
\hline 1 & 43 & 0.861 & global financial crisis \\
\hline 2 & 41 & 0.848 & national culture \\
\hline
\end{tabular}




\begin{tabular}{llll}
\hline 3 & 37 & 0.886 & positive research \\
\hline 4 & 37 & 0.938 & capital approach \\
\hline 5 & 36 & 0.798 & seasoned equity offering underperformance \\
\hline 6 & 35 & 0.869 & real earnings management \\
\hline 7 & 29 & 0.711 & transition economy \\
\hline
\end{tabular}

These clustering keywords are important themes in the field of IFRS research, including global accounting convergence, global financial crisis, national culture, positive research, capital approach, seasoned equity offering underperformance, real earnings management, transition economy.

\subsubsection{Burst Hot Spot and Trend Analysis}

Burst hotspots refer to topics that appear suddenly and are highly concerned by the academic community and are generally related to specific environments or events. Based on Figure 8, we check the Burstness view and get a total of 17 burst keywords (Table 9).

Table 9. Top 17 keywords with the strongest citation bursts

\begin{tabular}{|c|c|c|c|c|}
\hline Keywords & Strength & Begin & End & $2009-2020$ \\
\hline fair value & 4.7455 & 2009 & 2011 & 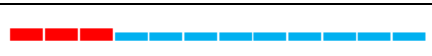 \\
\hline $\begin{array}{ll}\text { international } \\
\text { standard }\end{array}$ & 6.6442 & 2009 & 2012 & \\
\hline harmonization & 4.4299 & 2010 & 2013 & - \\
\hline $\begin{array}{ll}\text { international } & \text { financial } \\
\text { reporting standards (IFRS) }\end{array}$ & 3.8354 & 2011 & 2014 & 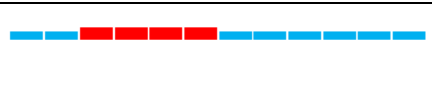 \\
\hline comparability & 3.6185 & 2011 & 2012 & 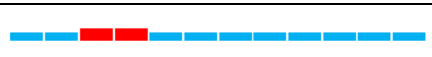 \\
\hline legal & 2.9817 & 2011 & 2014 & 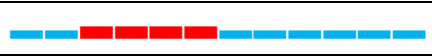 \\
\hline home bias & 2.9321 & 2011 & 2015 & 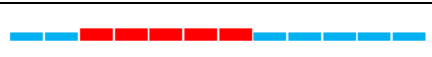 \\
\hline international accounting & 5.1176 & 2011 & 2014 & 2-1 \\
\hline market reaction & 4.0398 & 2012 & 2014 & 2-16-1 \\
\hline price & 2.769 & 2013 & 2014 & 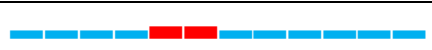 \\
\hline conceptual framework & 2.9272 & 2014 & 2017 & $-1-1-1=$ \\
\hline government & 2.9527 & 2014 & 2016 & 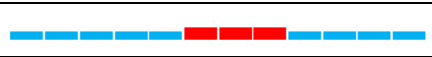 \\
\hline perspective & 3.9989 & 2016 & 2018 & 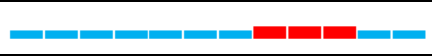 \\
\hline goodwill impairment & 2.6902 & 2016 & 2018 & -டிடாடி \\
\hline construction & 3.0038 & 2017 & 2020 & \\
\hline information environment & 4.0002 & 2017 & 2018 & 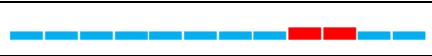 \\
\hline listed company & 2.6648 & 2017 & 2018 & 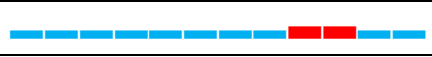 \\
\hline
\end{tabular}

Table 9 shows that since 2009, IFRS research bursts can be divided into three stages. The hot spots that emerged from 2009 to 2011 mainly focused on the discussion of the concepts of IAS and IFRS, including comparability, legal issues, home bias, etc. The hot spots that emerged from 2012 to 2014 turned to theoretical discussions, including market reaction, government supervision, and the impact on stock value. Since 2016, we have started to research some practical aspects, including goodwill impairment, construction, information environment, and listed company. We predict that due to the issuance of IASB financial reporting framework 2018 (effective from 2020) keyword 'conceptual framework' is going to be one of hot research topic from 2020 onwards. 


\section{Discussions and Conclusions}

The IFRS rapidly entered our lives at the beginning of this century and have since become an integral part of the economic life of almost every country on the planet. To better comprehend the cascading increase in global research on IFRS, we embarked to conduct a scientometric review of 973 articles related to the issue published during the period from 2009 to 2020 and indexed in the Web of Science Core Collection. The last decade was a decade of formative years of IFRS as global standards and its rapid adaption throughout the world what explains our choice of the period covered. We use CiteSpace as a tool for data statistics and knowledge graph drawing.

Our main findings are:

(1) Time and geographical distribution of articles published. Since 2009, the overall trend in the number of articles published in IFRS research has continued to increase. There are 27 countries (regions) with more than 10 IFRS research articles. The five countries with the largest number of IFRS studies are the United States, England, Australia, China, and Germany, which are located in North America, Europe, Australia and Asia. In order of importance of the article, the top 5 countries are England, the United States, Australia, New Zealand, and Germany.

(2) The institutional distribution of the article. The main research institutions of IFRS are universities, and the cooperation network between research institutions is relatively loose, and no high-intensity cooperation has been found. Among the 310 research institutions involved in our research, only 8 have published more than 5 articles, with an average of 2.58 articles. The universities with the largest number of articles are mainly from Australia, UK, New Zealand, the United States, and Romania.

(3) The author cited. 26 authors have been cited more than 3 times. The top 5 are Christopher Nobes, Christian Leuz, Sidney J Gray, Ann Tarca, and Christian Stadler. Generally speaking, as an emerging research topic, there are not many IFRS papers and fewer citations in the literature.

(4) Hot articles. Within the last half a year (from August 2020) and since 2013, the documents used in IFRS research are the same. The main hot articles include Byard, Li, \& Yu's article on the impact of mandatory adoption of IFRS on the information environment of financial analysts (2011), DeFond, Hu, Hung, \& Li's study on the impact of mandatory adoption of IFRS on foreign mutual fund ownership from the perspective of comparability (2011) and Horton, Serafeim, \& Serafeim's paper studying whether the mandatory adoption of IFRS can improve the information environment (Horton, Serafeim, \& Serafeim, 2013).

(4) Co-occurrence of hot keywords. The top 10 keywords related to IFRS topics are earnings management, information, quality, disclosure, accounting standard, impact, standard, value relevance, earnings, and adoption. These core keywords correspond to hot research topics in the corresponding fields, including earnings management, information disclosure quality, accounting standards, the impact of IFRS, value relevance, and IFRS adoption. The hot keywords in IFRS research include ownership, performance, firm, director, and determine which belong to financial performance, board characteristics, agency issues, equity structure, and social responsibility. The top 5 hot issues in IFRS research are agency theory, emerging market, capital structure, family firms, and real earnings management.

(5) Clustering of hot keywords. Important themes in the field of IFRS research include global accounting convergence, global financial crisis, national culture, positive research, capital approach, seasoned equity offering underperformance, real earnings management, transition economy.

(6) Research hotspots of bursting. Since 2009, IFRS research bursts can be divided into three stages. The period from 2009 to 2011 mainly focused on the discussion of the concepts of IAS and IFRS, the period from 2012 to 2014 turned to the theoretical level, and the period from 2016 to 2020 was the research on the practical level.

There are some we believe important conclusions and implications for future research we can draw from our study. First, the manifold increase in the number of journal articles published in this field testifies to an expanded research interest in IFRS research. Yet, compared to other similar fields it wouldn't be an exaggeration to postulate that IFRS research still is a fledgling field in terms of scholarly output in peer-reviewed sources. Even taking into account the fact that the times of active adoption of IFRS by countries (and, accordingly, a significant increase in empirical research) have passed this area still has significant potential for growth and, consequently, to a better understanding of the essence of IFRS and peculiarities of their functioning in each given jurisdiction.

Second, global research on IFRS has been produced chiefly in the USA, England and Australia which not only generated majority of the high-yielding research institutions as well as productive authors but also countries of origins most of the prolific journals. This becomes more obvious if we poor over the objects of empirical research of 
the analyzed articles: there is the prevalence of white spots on the world map than coloured ones when it comes to empirical studies of IFRS. This, in turn, reinforces our suggestions for ample potential for growth in IFRS research, especially in countries left uncovered to the date.

Our paper's results should be considered together with its limitations. First, the search queries may not have been comprehensive enough to include all papers covering IFRS research. As a way to smooth this limitation, multiple queries are recommended for sample selection in subsequent research. Second, we utilize only one database; moreover, we also analyze articles only in English, which inevitably makes our sample incomplete, as there is at least one comparative database - Scopus - with comparable international significance (although Web of Science and Scopus overlap significantly as " 84 per cent of the WoS titles are also indexed in Scopus and 54 per cent of the Scopus titles are also indexed in WoS" (Gavel \& Iselid, 2008, p. 17)) and many papers in a language other than English. Third, we in terms of results generation rely on CiteSpace software which "may be affected by algorithm noise and sampling bias" (Gao, Ding, \& Wu, 2020). Finally, the scientometrics approach has an intrinsic weakness sewn into its premise relating to the motivation behind the paper's citation. It assumes that paper is cited when the idea (concept, thought) catches the interest of readers without considering other incentives and motivations that may spur authors into action and to include prior publications in its references list.

In closing, we believe that other types of documents (like book chapters, proceedings papers, conference papers) that are indexed in both databases (WoS Core collection and Scopus), as well as other high-quality publications indexed in other databases, may supply further information on this realm. Therefore, future review papers can employ CiteSpace to examine additional papers pertaining to IFRS thus enlarging and detailing the field further. It would also be of interest too if the results could be contrasted with those of this paper.

\section{References}

Abad, D., Cutillas-Gomariz, M. F., Sánchez-Ballesta, J. P., \& Yagüe, J. (2018). Does IFRS Mandatory Adoption Affect Information Asymmetry in the Stock Market? Australian Accounting Review, 28(1), 61-78. https://doi.org/10.1111/auar.12165

Abdullah, H., \& Tursoy, T. (2019). Capital structure and firm performance: evidence of Germany under IFRS adoption. Review of Managerial Science. https://doi.org/10.1007/s11846-019-00344-5

Ahmed, A. S., Neel, M., \& Wang, D. (2013). Does Mandatory Adoption of IFRS Improve Accounting Quality? Preliminary Evidence. Contemporary Accounting Research, 30(4), 1344-1372. https://doi.org/10.1111/j.1911-3846.2012.01193.x

Barth, M. E., \& Israeli, D. (2013). Disentangling mandatory IFRS reporting and changes in enforcement. Journal of Accounting and Economics, 56(2-3), 178-188. https://doi.org/10.1016/j.jacceco.2013.11.002

Barth, M. E., Landsman, W. R., \& Lang, M. H. (2008). International Accounting Standards and Accounting Quality. Journal of Accounting Research, 46(3), 467-498. https://doi.org/10.1111/j.1475-679X.2008.00287.x

Black, E. L. (2012). IFRS Convergence and Adoption: Challenges and Opportunities. Journal of International Accounting Research, 11(1), 1-3. https://doi.org/10.2308/jiar-10230

Brochet, F., Jagolinzer, A. D., \& Riedl, E. J. (2013). Mandatory IFRS Adoption and Financial Statement Comparability. Contemporary Accounting Research, 30(4), 1373-1400. https://doi.org/10.1111/1911-3846.12002

Brown, P. (2011). International Financial Reporting Standards: what are the benefits?. Accounting and Business Research, 41(3), 269-285. https://doi.org/10.1080/00014788.2011.569054

Brown, P., Preiato, J., \& Tarca, A. (2014). Measuring Country Differences in Enforcement of Accounting Standards: An Audit and Enforcement Proxy. Journal of Business Finance \& Accounting, 41(1-2), 1-52. https://doi.org/10.1111/jbfa.12066

Burgstahler, D. C., Hail, L., \& Leuz, C. (2006). The Importance of Reporting Incentives: Earnings Management in European Private and Public Firms. The Accounting Review, 81(5), 983-1016. https://doi.org/10.2308/accr.2006.81.5.983

Byard, D., Li, Y., \& Yu, Y. (2011). The Effect of Mandatory IFRS Adoption on Financial Analysts' Information Environment. Journal of Accounting Research, 49(1), 69-96. https://doi.org/10.1111/j.1475-679X.2010.00390.x

Cao, J., \& Patel, C. (2019). The role of the national institutional environment in IFRS convergence: a new approach. Accounting \& Finance, acfi.12525. https://doi.org/10.1111/acfi.12525 
Chen, C. (2004). Searching for intellectual turning points: Progressive knowledge domain visualization. Proceedings of the National Academy of Sciences, 101(Supplement 1), 5303-5310. https://doi.org/10.1073/pnas.0307513100

Chen, C. (2017). Science Mapping: A Systematic Review of the Literature. Journal of Data and Information Science, 2(2), 1-40. https://doi.org/10.1515/jdis-2017-0006

Chen, D., Liu, Z., Luo, Z., Webber, M., \& Chen, J. (2016). Bibliometric and visualized analysis of emergy research. Ecological Engineering, 90, 285-293. https://doi.org/10.1016/j.ecoleng.2016.01.026

Clarivate Analytics. (n.d.). Web of Science Platform. Retrieved September 9, 2020, from https://clarivate.com/webofsciencegroup/solutions/webofscience-platform/

d'Arcy, A., \& Tarca, A. (2018). Reviewing IFRS Goodwill Accounting Research: Implementation Effects and Cross-Country Differences. The International Journal of Accounting, 53(3), 203-226. https://doi.org/10.1016/j.intacc.2018.07.004

Daske, H., Hail, L., Leuz, C., \& Verdi, R. (2013). Adopting a Label: Heterogeneity in the Economic Consequences Around IAS/IFRS Adoptions. Journal of Accounting Research, 51(3), 495-547. https://doi.org/10.1111/1475-679X.12005

de Bellis, N. (2014). History and Evolution of (Biblio)Metrics. In Beyond Bibliometrics. The MIT Press. https://doi.org/10.7551/mitpress/9445.003.0004

De George, E. T., Li, X., \& Shivakumar, L. (2016). A review of the IFRS adoption literature. Review of Accounting Studies, 21(3), 898-1004. https://doi.org/10.1007/s11142-016-9363-1

DeFond, M., Hu, X., Hung, M., \& Li, S. (2011). The impact of mandatory IFRS adoption on foreign mutual fund ownership: The role of comparability. Journal of Accounting and Economics, 51(3), 240-258. https://doi.org/10.1016/j.jacceco.2011.02.001

Florou, A., \& Pope, P. F. (2012). Mandatory IFRS Adoption and Institutional Investment Decisions. The Accounting Review, 87(6), 1993-2025. https://doi.org/10.2308/accr-50225

Gao, H., Ding, X.-H., \& Wu, S. (2020). Exploring the domain of open innovation: Bibliometric and content analyses. Journal of Cleaner Production, 275, 122580. https://doi.org/10.1016/j.jclepro.2020.122580

Garfield, E. (1955). Citation Indexes for Science: A New Dimension in Documentation through Association of Ideas. Science, 122(3159), 108-111. https://doi.org/10.1126/science.122.3159.108

Gavel, Y., \& Iselid, L. (2008). Web of Science and Scopus: a journal title overlap study. Online Information Review, 32(1), 8-21. https://doi.org/10.1108/14684520810865958

Hail, L., Leuz, C., \& Wysocki, P. (2010). Global Accounting Convergence and the Potential Adoption of IFRS by the U.S. (Part I): Conceptual Underpinnings and Economic Analysis. Accounting Horizons, 24(3), 355-394. https://doi.org/10.2308/acch.2010.24.3.355

Hasan, M. M., Cheung, A. Wai, K., \& Taylor, G. (2020). Financial statement comparability and bank risk-taking. Journal of Contemporary Accounting \& Economics, 16(3), 100206. https://doi.org/10.1016/j.jcae.2020.100206

Horton, J., Serafeim, G., \& Serafeim, I. (2013). Does Mandatory IFRS Adoption Improve the Information Environment?*. Contemporary Accounting Research, 30(1), 388-423. https://doi.org/10.1111/j.1911-3846.2012.01159.x

Huang, Y., \& Yan, C. (2020). Global accounting standards, financial statement comparability, and the cost of capital. International Review of Economics \& Finance, 69, 301-318. https://doi.org/10.1016/j.iref.2020.05.019

IFRS Foundation. (2019). Who uses IFRS Standards?. Retrieved September 28, 2019, from https://www.ifrs.org/use-around-the-world/use-of-ifrs-standards-by-jurisdiction/

Jang, J. I., Lee, K. J., Seo, Y., \& Cheung, J. (2016). Economic Consequences Of IFRS Adoption In Korea: A Literature Review. Journal of Applied Business Research (JABR), 32(6), 1649. https://doi.org/10.19030/jabr.v32i6.9813

Khlif, H., \& Achek, I. (2016). IFRS adoption and auditing: a review. Asian Review of Accounting, 24(3), 338-361. https://doi.org/10.1108/ARA-12-2014-0126

Kim, M. C., \& Chen, C. (2015). A scientometric review of emerging trends and new developments in recommendation systems. Scientometrics, 104(1), 239-263. https://doi.org/10.1007/s11192-015-1595-5 
Kvaal, E., \& Nobes, C. (2010). International differences in IFRS policy choice: A research note. Accounting and Business Research, 40(2), 173-187. https://doi.org/10.1080/00014788.2010.9663390

Leuz, C. (2010). Different approaches to corporate reporting regulation: How jurisdictions differ and why. Accounting and Business Research, 40(3), 229-256. https://doi.org/10.1080/00014788.2010.9663398

Leuz, C., \& Wysocki, P. D. (2016). The Economics of Disclosure and Financial Reporting Regulation: Evidence and Suggestions for Future Research. Journal of Accounting Research, 54(2), 525-622. https://doi.org/10.1111/1475-679X.12115

Leuz, C., Nanda, D., \& Wysocki, P. D. (2003). Earnings management and investor protection: an international comparison. Journal of Financial Economics, 69(3), 505-527. https://doi.org/10.1016/S0304-405X(03)00121-1

Leydesdorff, L., \& Milojević, S. (2012). Scientometrics. Retrieved from http://arxiv.org/abs/1208.4566

Li, S. (2010). Does Mandatory Adoption of International Financial Reporting Standards in the European Union Reduce the Cost of Equity Capital?. The Accounting Review, 85(2), 607-636. https://doi.org/10.2308/accr.2010.85.2.607

Liu, W. (2019). The data source of this study is Web of Science Core Collection? Not enough. Scientometrics, 121(3), 1815-1824. https://doi.org/10.1007/s11192-019-03238-1

Merz, A. (2017). What have we learned from SFAS 123r and IFRS 2? A review of existing evidence and future research suggestions. Journal of Accounting Literature, 38, 14-33. https://doi.org/10.1016/j.acclit.2017.06.001

Mingers, J., \& Leydesdorff, L. (2015). A Review of Theory and Practice in Scientometrics. https://doi.org/10.1016/j.ejor.2015.04.002

Nobes, C. (2006). The survival of international differences under IFRS: towards a research agenda. Accounting and Business Research, 36(3), 233-245. https://doi.org/10.1080/00014788.2006.9730023

Păşcan, I.-D. (2015). Measuring the Effects of IFRS Adoption on Accounting Quality: A Review. Procedia Economics and Finance, 32, 580-587. https://doi.org/10.1016/S2212-5671(15)01435-5

Riahi, O., \& Khoufi, W. (2019). Understanding IFRS adoption. Journal of Applied Accounting Research, 20(4), 543-570. https://doi.org/10.1108/JAAR-02-2017-0034

Rousseau, R., Egghe, L., \& Guns, R. (2018). Becoming metric-wise: A bibliometric guide for researchers. Cambridge, MA: Chandos Publishing.

Shiffrin, R. M., \& Borner, K. (2004). Mapping knowledge domains. Proceedings of the National Academy of Sciences, 101(Supplement 1), 5183-5185. https://doi.org/10.1073/pnas.0307852100

Tawiah, V., \& Boolaky, P. (2019). A review of literature on IFRS in Africa. Journal of Accounting \& Organizational Change, 16(1), 47-70. https://doi.org/10.1108/JAOC-09-2018-0090

Tsalavoutas, I., Tsoligkas, F., \& Evans, L. (2020). Compliance with IFRS mandatory disclosure requirements: A structured literature review. Journal of International Accounting, Auditing and Taxation, 40, 100338. https://doi.org/10.1016/j.intaccaudtax.2020.100338

Wadesango, N., Tasa, E., Milondzo, K., \& Wadesango, O. V. (2016). A literature review on the impact of IAS/IFRS and regulations on quality of financial reporting. Risk Governance and Control: Financial Markets and Institutions, 6(4). https://doi.org/10.22495/rcgv6i4art13

Wu, Y., Wang, H., Wang, Z., Zhang, B., \& Meyer, B. C. (2019). Knowledge Mapping Analysis of Rural Landscape Using CiteSpace. Sustainability, 12(1), 66. https://doi.org/10.3390/su12010066

Wysocki, P. (2011). New institutional accounting and IFRS. Accounting and Business Research, 41(3), 309-328. https://doi.org/10.1080/00014788.2011.575298

\section{Copyrights}

Copyright for this article is retained by the author(s), with first publication rights granted to the journal.

This is an open-access article distributed under the terms and conditions of the Creative Commons Attribution license (http://creativecommons.org/licenses/by/4.0/). 